\title{
THE USE OF DISCOURSE COMPLETION TASK (DCT) AS EXPLICIT INSTRUCTION ON INDONESIAN EFL LEARNERS' PRODUCTION OF SUGGESTION ACTS
}

\author{
Fauzul Aufa \\ University of Queensland
}

\begin{abstract}
There are some activities that can be developed to bring up EFL learners' pragmatic awareness, such as contextualized language practice in given situations, constructed peer dialogues, and metapragmatic discussions. This task-based approach used in these activities can be either explicit or implicit instruction. One of them is a metapragmatic discussion prompted by Discourse Completion Task (DCT). In this paper, DCT, as an explicit pragmatic instruction, was practically investigated its effectiveness to facilitate EFL learners in developing their pragmatic competence. The results demonstrated from the analysis of RP2 prompted by the DCT support the fact that the explicit instruction results in some variations of linguistic forms that contribute to the development of subjects' pragmatic competence
\end{abstract}

Key words : Discourse Completion Task (DCT), pragmatic competence, explicit pragmatic instruction, English as a Foreign Language (EFL).

\section{INTRODUCTION}

Pragmatic competence has been essentially recognized as one of the factors to perceive learners' communicative competence. Many research studies on pragmatic competence have affirmed that even proficient English learners often use language inappropriately (Hinkel, 1997; Bardovi-Harglig, 1999; MartinezFlor, 2003; Jianda, 2006; Jiang, 2006; Decapua \& Dunham, 2007; Bu, 2011; Phisghadam \& Sharafadini, 2011). In other words, proficiency in a target language does not only involve grammatical competence, but it also requires pragmatic competence. Communication breakdowns may happen if the learners are not knowledgeable of social, cultural, and discourse aspects in different situations 
bound with the language they produce. Mostly, research in interlanguage pragmatic (ILP) compared between English native speakers (NS) and non-native speakers (NNS) in realising the speech act strategies when they use the language (Matsumura, 2003; Schauer, 2006; Felix-Brasdefer, 2007; Grossi, 2009; Jalilifar, Hashemian, \& Tabatabaee, 2011). Since Kasper and Schmidt (1996) argue that ILP has notably involved within the larger body of Second Language Acquisition (SLA) studies, it starts attracting researchers to examine the effects of instruction on ILP development. Still, little research has been conducted on how instruction plays an important role in learners' pragmatic development (Alcon, 2005; Martinez-Flor \& Uso-Juan, 2006). Thus, the aim of this report was to briefly investigate the practical use of Discourse Completion Task (DCT) as an explicit instruction on Indonesian EFLlearners' production of suggestion acts in English in terms of the variety of linguistic formulations.

Regarding the development of learner's pragmatic competence, there are some useful activities aimed at raising their pragmatic awareness, such as presentation and discussion guided by the teacher, translation, dramas, simulations, and role-play activity. This task-based approach used in these activities can be either explicit or implicit instruction. The main difference is that explicit instruction provides learners with detailed metapragmatic explanations about target-structure forms, functions, and why certain forms are culturally preferred, while implicit instruction does not. Several research studies have investigated and compared the effect of explicit and implicit instruction on pragmatic enhancement (Safont-Jorda, 2003; Eslami-Rasekh, 2005; Suh, 2009). In spite of some exclusions, Rose (2005) and Chen (2009) asserts that most of intervention studies to date have shown that learners who get explicit instruction perform better than those who get implicit instruction. Moreover, explicit instruction in language learning assists learners not only to improve learners' grammatical competence, but also to develop their pragmatic awareness.

Therefore, one of the explicit instructions used in this study was a discussion prompted by the DCT. Most of ILP studies have collected the data mainly taken from the production of responses to written prompts in a DCT. However, the DCT may practically have potential use to initiate learners' pragmatic awareness that leads to the development of their pragmatic competence. As a focus of this study, learners' production of suggestion acts in English was considered since giving suggestion is commonly used in daily interaction particularly in the campus 
setting, between a learner and a lecturer or among learners. Furthermore, this type of speech act is rarely investigated compared to other speech acts, such as request, compliment, apology, and refusal acts.

\section{RESEARCH QUESTION}

The research question investigated was as follow.

"Does the use of DCT as an explicit instruction produce more variations of linguistic forms on Indonesian EFL learners' production of suggestion acts in English?”

\section{METHOD}

\section{Subjects}

For the concern of the present study, two Indonesian students studying at University of Queensland were randomly selected. To ensure their English proficiency level was relatively the same, their IELTS scores were taken into account. The selection of the subjects was done on the basis of the following criteria: a) they were Indonesian students and could actively speak English; b) they were male or female with ranging in age from 23 to 40; c) they have studied English subject at least 6 years; and d) they agreed to be chosen as subjects of the study.

\section{Instrument}

Role-play was used to collect data. In the role-play, the scenarios in the DCT were based on certain variables, which determined appropriate level of politeness for suggestion-giving (Brown \& Levinson, 1978). They were social distance (D), relative power $(\mathrm{P})$, and the degree of imposition $(\mathrm{R})$. $\mathrm{D}$ and $\mathrm{P}$ were controlled to reflect interactions commonly observed in an academic context in campus. Unlike the other two variables, $\mathrm{R}$ which may affect subjects' strategy choice in interaction, was not specifically mentioned in the description of the role play. However, the description of the social distance (+/- D) and power (+/- P) in each scenario may affect on the degree of imposition of the suggestion. To put it in another way, from the contextual description given for each situation (+/- D, +/-P), the subjects would infer the weight of imposition required for each suggestion situation. 
There were five different constellations with two situations each given to the students (see Appendix 3). They took at least two minutes to have oral production to play each situation. Before playing the roles, one of the subjects was instructed to read the role-play situation carefully and to respond as they were in a natural conversation. During the data collection, the author noted down what was happening in the role-play. The videotaped role-plays were subsequently transcribed.

\section{Procedure}

In order to do preliminary assessment of subjects' pragmatic competence in suggestion act, they were firstly assigned to do a role-play prompted in the DCT. Having completed the first role-play (RP1), which took about 15 minutes, the author led a discussion about the same DCT before assigning them to have the second role-play (RP2). The author explained scenarios and the cultural variables (relative power (+/-P), social distance (+/-D), and degree of imposition (+/-R)) in the DCT. In addition, the author gave more examples of giving suggestion and let them work in pair to prepare RP2. The subjects practiced their verbal answers that corresponded to each situation given in the DCT. In this study, the DCT was used not only to assess their production of suggestion act, but also to assist them in the discussion before performing RP2.

\section{Data Analysis}

The data collected were reduced and analyzed according to a modified taxonomy of the suggestion strategies by Martinez-Flor (2005) (see Appendix 1). In the present study, suggestions were examined according to the type of strategies, internal, and external modifications. The suggestion head acts were codified based on three degrees of directness: 1) direct forms (DF); 2) conventionalized forms (CF); and 3) indirect forms (IF). Each level of directness comprised various substrategies. For example, in $\mathrm{CF}$ suggestions, the suggestion perspective was analyzed according to the specific formulae, such as the use of interrogative forms, or the use of modal to show possibility (e.g., can, may, could, and might), or whether the suggestion uses 'should' or 'need', or by using conditional forms (e.g., If I were you, I would...). Unlike direct and conventionalized forms, indirect suggestions contained only two strategies, namely: impersonal and hint. The 
analysis of the suggestion head act included an examination of the internal modifications of the suggestion that served as mitigators (e.g., syntactic and lexical downgraders) proposed by Trosborg (1995) (see Appendix 2). On the other hand, external modifications involved four supportive moves that either will proceed or follow a suggestion head act, namely: grounders, preparators, imposition minimizers, and disarmers.

\section{RESULTS}

For the purpose of the present study, the author has concentrated on one feature of subjects' pragmatic competence, namely the production of suggestion formulation. In order to analyse the instructional effects on variety of linguistic suggestion forms, the author compared the use of suggestion formulas quantitatively (the amount of strategies produced between RP1 and RP2). In response to the research question, the statistical analysis indicated that there was a slight difference between RP1 and RP2 as shown in Figure 1 below.

\section{Overall Suggestion Strategy Use}

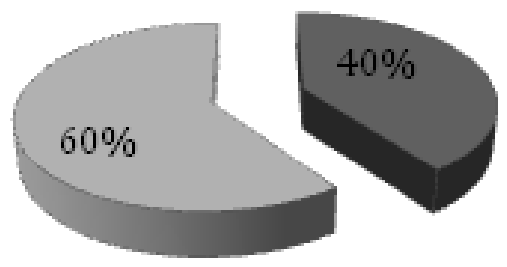

Role-play 1

Role-play 2

Figure 1. Overall suggestion strategy used before and after treatment 
Figure 1 above shows an increase in the number of strategies used as the effect of instruction given. In terms of variety of suggestion strategies used in RP1, conventionalized forms (interrogative and should forms) were the most commonly used types followed by indirect (hints) and direct forms (imperatives) (see Table 1). In contrast, the subjects in RP2 frequently used indirect forms (hints and impersonal) followed by direct (imperatives and negative imperatives) and conventionalized forms (possibility, should, and conditional) (see Table 1).

Table 1. Frequency of Suggestion Strategies Used in RP1 and RP2

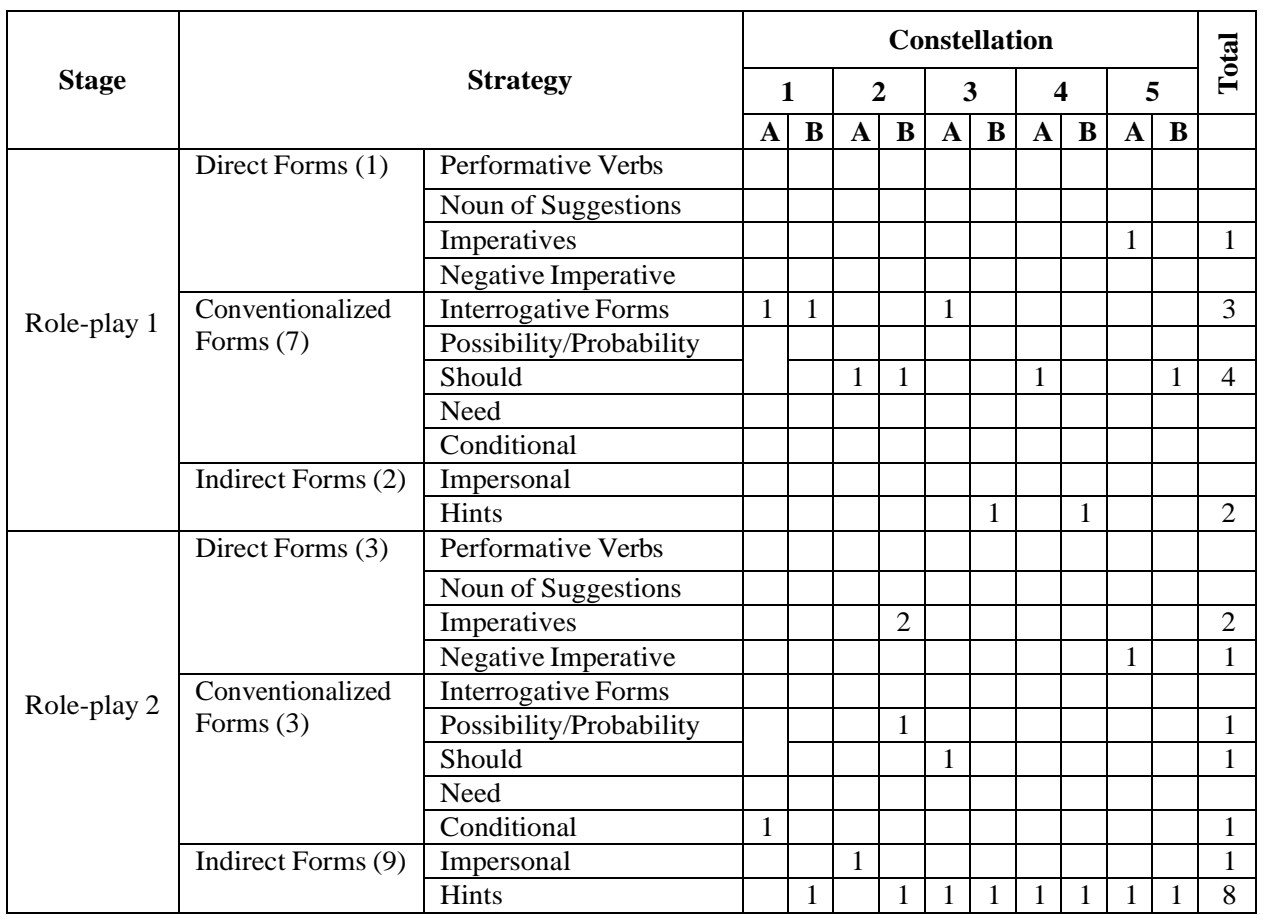

At this stage, the author may state that findings in regard with the subjects' performance before and after this research took place showed the effect of instruction. Even though they did not seem to show more variations of linguistic forms and its distribution employed in RP2, there was a small increase of number of suggestion strategies used particularly in indirect forms and an equal number between the use of direct and conventionalized forms (as shown in Figure 2). 


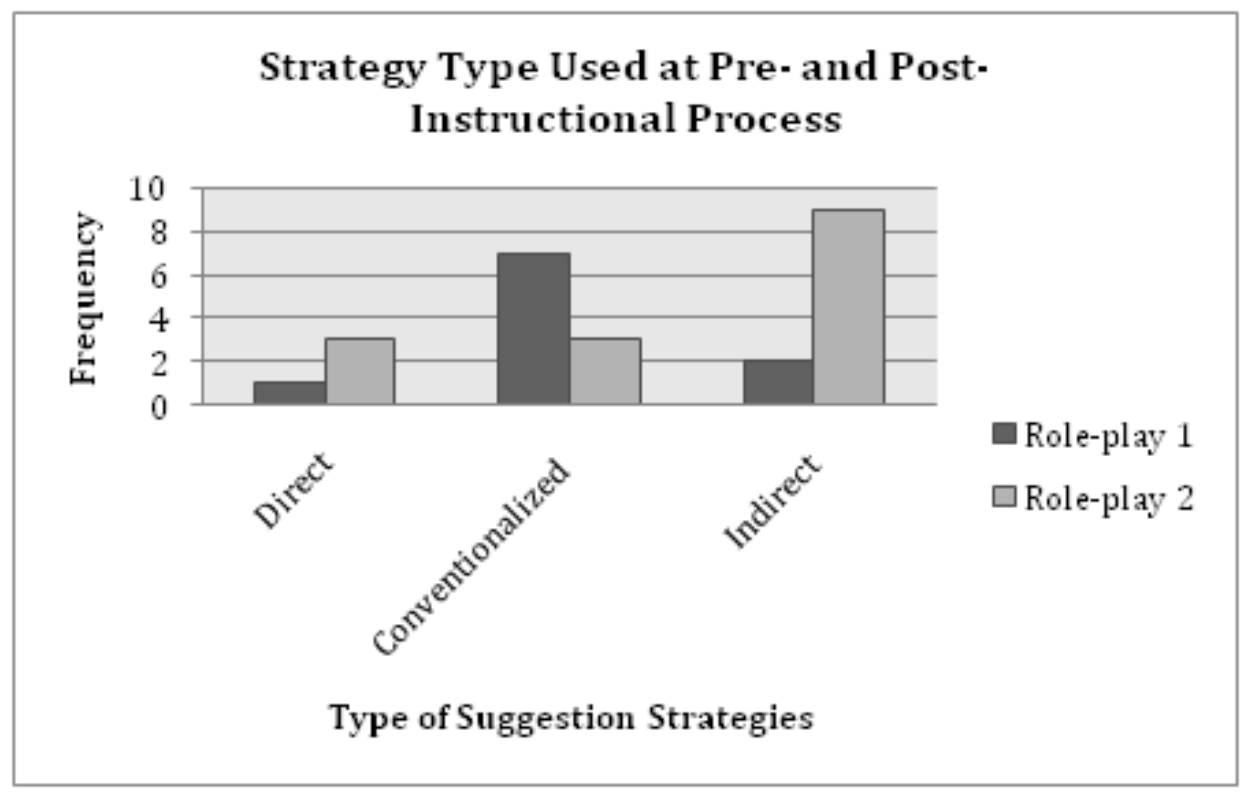

Figure 2. Suggestion Strategy Type Used at Pre- and Post-Instructional Process

Apart from analysing the suggestion strategy types used in both role-plays, this study also considered the variety of linguistic formulations in terms of external and internal modifications made by the subjects in realising suggestion strategies (see Table 2). These modifiers were used to increase or decrease the force of the subjects' suggestion on the hearer. 
Table 2. Frequency of External and Internal Modifications in Suggestion Used in RP1 and RP2

\begin{tabular}{|c|c|c|c|c|c|c|c|c|c|c|c|c|c|c|}
\hline \multirow{3}{*}{ Stage } & & \multirow{3}{*}{\multicolumn{2}{|c|}{ Type of Modification }} & \multicolumn{10}{|c|}{ Constellation } & \multirow{3}{*}{ 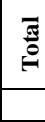 } \\
\hline & & & & \multicolumn{2}{|c|}{1} & \multicolumn{2}{|c|}{2} & \multicolumn{2}{|c|}{3} & \multicolumn{2}{|c|}{4} & \multicolumn{2}{|c|}{5} & \\
\hline & & & & $\mathbf{A}$ & B & $\mathbf{A}$ & $\mathbf{B}$ & $\mathbf{A}$ & $\mathbf{B}$ & $\mathbf{A}$ & B & $\mathbf{A}$ & $\mathbf{B}$ & \\
\hline \multirow{12}{*}{ Role-play 1} & \multirow{4}{*}{\multicolumn{2}{|c|}{ External }} & Grounder & & 1 & & 1 & 1 & & 1 & & 1 & 1 & 6 \\
\hline & & & Preparator & & & & & & & & & & & \\
\hline & & & Imposition Minimizer & & & & & & & & & & & \\
\hline & & & Disarmer & & & & & & & & & & & \\
\hline & \multirow{8}{*}{ Internal } & \multirow{3}{*}{$\begin{array}{c}\text { Syntatic } \\
\text { Downgrader }\end{array}$} & Conditional Clause & & & & & & & & & & & \\
\hline & & & Interrogative & & & & & & & & & & & \\
\hline & & & Negation & & & & & & & & & & & \\
\hline & & \multirow{5}{*}{$\begin{array}{c}\text { Lexical } \\
\text { Downgrader }\end{array}$} & Appealer & & & & & & & & & & & \\
\hline & & & Hedge & & & & & & & & & & & \\
\hline & & & Politeness Marker & & & & & & & & & & & \\
\hline & & & Subjectivizer & & & 1 & 1 & & & 1 & 1 & & & 4 \\
\hline & & & Understater & & & & & 1 & & & & & & 1 \\
\hline \multirow{12}{*}{ Role-play 2} & \multirow{4}{*}{\multicolumn{2}{|c|}{ External }} & Grounder & & 1 & 1 & 1 & 1 & & 1 & & & 1 & 6 \\
\hline & & & Preparator & & & & & & & & & & & \\
\hline & & & Imposition Minimizer & & & & & & & & & & & \\
\hline & & & Disarmer & & & & & & & & & & & \\
\hline & \multirow{8}{*}{ Internal } & \multirow{3}{*}{$\begin{array}{c}\text { Syntactic } \\
\text { Downgrader }\end{array}$} & Conditional Clause & & & & & & & & & & & \\
\hline & & & Interrogative & & & & & & & & & & & \\
\hline & & & Negation & & & & & & & & & & & \\
\hline & & \multirow{5}{*}{$\begin{array}{c}\text { Lexical } \\
\text { Downgrader }\end{array}$} & Appealer & & & & 1 & & & & & & & 1 \\
\hline & & & Hedge & & & 1 & & & & & & & & 1 \\
\hline & & & Politeness Marker & & & & 2 & & & & & & & 2 \\
\hline & & & Subjectivizer & 1 & & 1 & & 1 & 1 & & 1 & 1 & & 6 \\
\hline & & & Understater & & & & & & & & & & & \\
\hline
\end{tabular}

As displayed in Table 2, the subjects in RP1 showed restricted use of internal and external modifiers. Only one type of external modifier used (grounder) and two types of internal modifier (subjectivizer and understater). In contrast, there was an increase number of linguistic variation employed by the subjects in RP2. They did not only use grounder and subjectivizer, but also employ appealer, hedge, and politeness marker. Therefore, there was a little difference in terms of the use of internal suggestion modifiers between RP1 and RP2 after the instructional process was conducted, as shown in Figure 3 below. 


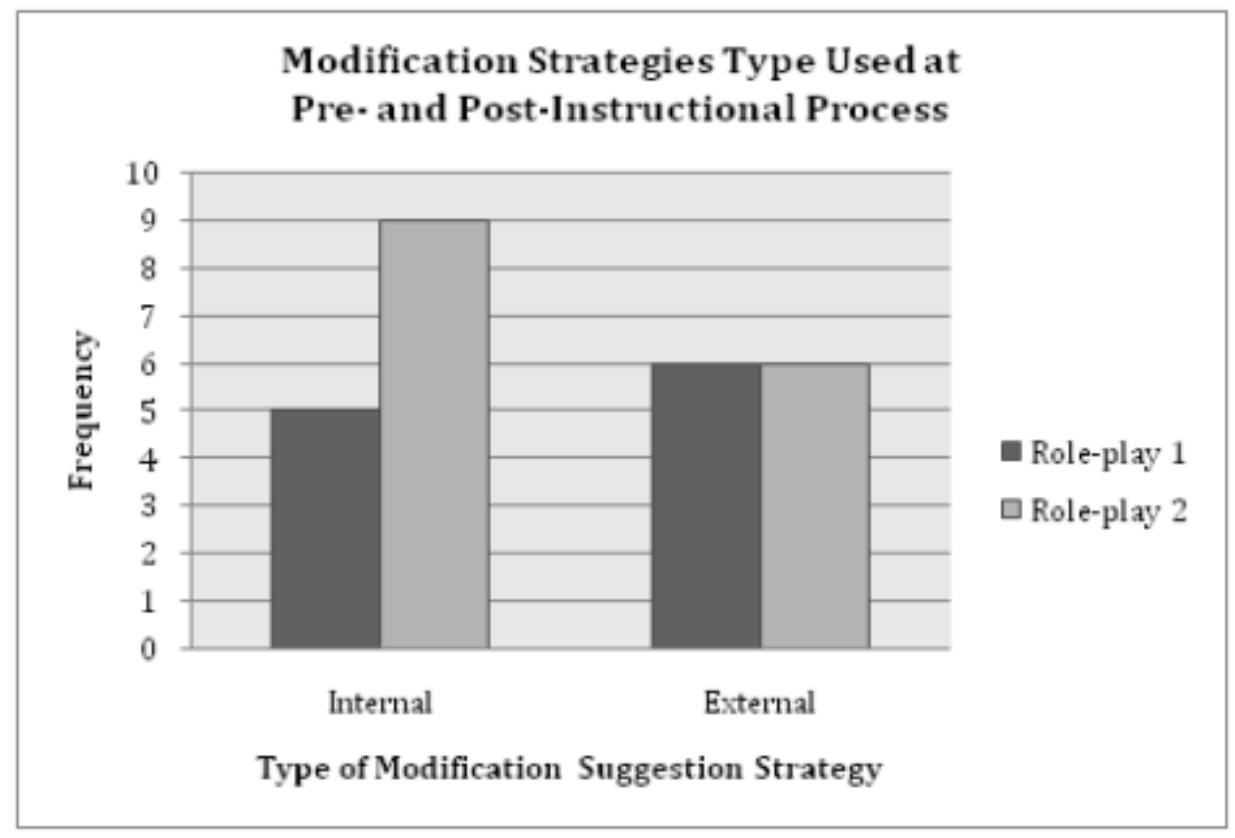

Figure 3. External and Internal Suggestion Modifiers Used at Preand Post-instructional Process

\section{DISCUSSION}

Results demonstrated from the analysis of RP2 prompted by the DCT support the fact that the explicit instruction results in some variations of linguistic forms that contribute to the development of subjects' pragmatic competence. In addition, Kasper and Schmidt (1996) assert that the explicit instruction encloses two activities that not only raise learners' pragmatic awareness, but also provide opportunities for communicative and practical use. Following Martinez-Flor (2004), the present study indicates that the subjects increased their input of suggestion act after applying the prompted DCT. Having explained explicitly some variables (social distance, power, and the degree of imposition) in each situation prompted in the DCT, the subjects noticed specific features of pragmatic input and guided them to make connections with linguistic features, pragmatic functions, social contexts and cultural meanings. As a result, this activity can develop the subjects' pragmatic competence in giving suggestion in English. 
Regarding learners' gain in awareness, the results of the present study seem to confirm Schmidt's (1993) noticing hypothesis which argues that learners are able to process certain input and turn it become intake until they consciously notice the input. For example, in situation B (constellation 1) in which a student tried to give some suggestion to his heavy-smoker lecturer and their relationship was not close, the subjects in RP1 only used 'interrogative form' (e.g. Why do you still smoke?) to his suggestion. In contrast, after the instructional process took place, the subjects in RP2 added his suggestion with 'grounder' or explain why he should stop smoking (e.g. it is not good) and used 'hints' suggestion strategy to address his lecturer. Hence, these modifiers employed showed an increase of subjects' awareness of suggestion realisation strategies. In other words, they can be considered as a sign of subjects' awareness of their pragmalinguistics and sociopragmatics knowledge even though the difference was not statistically significant between RP1 and RP2. However, this present study differs from Bu's (2012) study indicating that the subjects often unsuccessfully used their pragmalinguistics knowledge in order to have appropriate suggestions based on social contexts. Since learners find the linguistic realisation unclear and lack exposure to applicable input, it can be insufficient for acquisition of target language pragmalinguistics knowledge (Schmidt, 1993).

Focusing on the variation of linguistic formulation, the present study confirms previous research that shows lack of linguistic variation after the instructional process took place (Safont-Jorda, 2004). In particular, the number of suggestion strategies used did not seem to greatly vary after the instructional process (see Table 1). Nevertheless, the increase number of indirect forms (e.g. 'Hints') used does not imply to approve Trosborg's (1995) results which demonstrates that English learners did not commonly use 'hints' in the role-play task since the difficulty in making indirect suggestion, whereas in the present study the subjects frequently used 'hints' to suggest in RP2 as illustrated in Figure 2.

Additionally, the findings of the present study related to the aspect of external and internal modification use is similar to what Xiao-le's (2011) study, which revealed that the participants gained the use of internal and external suggestion modifiers. In the present study, the subjects did not only employ 'grounder' (providing explanations about the suggestions) and 'subjectivizer' (e.g. I think) to mitigate his suggestion, but they also used 'appealer' (e.g. you know), 'hedge' (e.g. right?), and 'politeness marker' (e.g. please) after the instructional 
process was conducted. Specifically, the frequency of internal modification on the use of lexical downgraders slightly increased to some extent in RP2. Accordingly, the practical use of DCT as the explicit instruction can be claimed as one of effective awareness-raising tasks and metapragmatic information sources.

However, the present study has few limitations. Firstly, the study focuses solely on the variety of linguistic formulations on Indonesian EFL learners' production of suggestion acts after the instruction given. In addition, more comprehensive study of the pedagogical use of DCT in the classroom is needed to get better results. Lastly, this study should have involved more participants to get reliable data. Thus, further research should be conducted to resolve these issues.

Ultimately, the following topics can be recommended for those who are interested in pragmatic competence and its relation to explicit instruction effectiveness. One similar research can be conducted based on the sex difference variable, which compare between male and female in giving suggestion. Further, regarding the possible impact of learners' proficiency level, another study can be done with subjects from three different level of proficiency, such as elementary, intermediate, and advanced level.

\section{CONCLUSION}

To sum up, this mini research aimed at examining the practical use of Discourse Completion Task (DCT) as the explicit instruction on Indonesian EFL learners' production of suggestion acts in English, particularly on their variation of linguistic formulations. The findings of this research generally contribute to previous studies on the effect of explicit instruction on target language learning (Safont-Jorda, 2003, 2004; Alcon, 2005; Rose, 2005; Chen, 2009; Bu, 2012). More specifically, it has illustrated the advantages of the DCT use on learners' pragmatic competence development in suggestion act. In light of the present results, at least two pedagogical implications can be recommended. Firstly, providing leaners with authentic input should be applied in EFL context in order to raise their pragmatic awareness. Lastly, various teaching techniques have to be functionalized in order to overcome issues on teaching pragmatic in the classroom. 


\section{REFERENCES}

Alcon, E. (2005). Does instruction work for learning pragmatics in the EFL context? System, 33(3), 417-435.

Bardovi-Harlig, K. (1999). Exploring the interlanguage of interlanguage pragmatics. Language Learning 49 (4), 677713.

Brown, P. \& Levinson, S. (1978). Politeness: Some universals in language use. New York: Cambridge University Press.

$B u, J .(2011)$. A study of pragmatic transfer in suggestion strategies by Chinese learners of English. Studies in Literature and Language, 3(2), 28-36. doi: 10.3968/j.sll.1923156320110302.325

$\mathrm{Bu}, \mathrm{J}$. (2012). Astudy of the effects of explicit and implicit teachings on developing EFL learners' pragmatic competence. International Journal of Language Studies, 6(3), 57-80.

Chen, Y. (2009). Learner perceptions of instruction in L2 pragmatics. English Language Teaching, 2(4), 154-161.

Decapua, A. \& Dunham, J.F. (2007). The pragmatics of advice giving: Crosscultural perspective. Intercultural Pragmatics, 4(3), 319-342. doi: 10.1515/IP.2007.016

Eslami-Rasekh, Z. (2005). Raising the pragmatic awareness of language learners. ELT Journal, 59(3), 199-208. doi:10.1093/elt/cci039

Felix-Brasdefer, J.C. (2007). Pragmatic development in the Spanish as a FL classroom: A cross-sectional study of learner requests. Intercultural Pragmatics, 4(2), 253-286. doi: 10.1515/IP.2007.013

Grossi, V. (2009). Teaching pragmatic competence: Compliment and compliment responses in the ESL classroom. Prospect Journal, 24(2), 53-62.

Hinkel, E. (1997). Appropriateness of advice: DCT and multiple choice data. Applied Linguistics, 18(1), 1-26. Retrieved from http://dx.doi.org/10.1093/applin/18.1.1.

Jalilifar, A., Hashemian, M., \& Tabatabaee, M. (2011). A cross-sectional study of Iranian EFL learners' request strategies. Journal of Language Teaching and Research, 2(4), 790-803. doi:10.4304/j1tr.2.4.790-803 
Jianda, L. (2006). Assessing EFL learners' interlanguage pragmatic knowledge: Implications for testers and teachers. Reflection on English Language Teaching, 5(1), 1-22.

Jiang, X. (2006). Suggestions: What should ESL students know? Elsevier, 34(1), $36-54$.

Kasper, G \& Schmidt, R. (1996). Developmental issues in interlanguage pragmatics. Studies in Second Language Acquisition, 18(2), 149-169.

Martinez-Flor, A. (2003). Non-native speakers' production of advice acts: The effects of proficiency. Revista Electronica de Linguistica Applicada, 16(2), 139-153.

Martinez-Flor, A. (2004). The effect of instruction on the development of pragmatic competence in the English as a foreign language context: A study based on suggestions. (Doctoral dissertation, Universitat Jaume I, $\left.\begin{array}{lllllll}2 & 0 & 0 & 4\end{array}\right) . \quad \mathrm{R}$ e $\mathrm{r}$ i e v e d f r o m www.tdx.cat/bitstream/handle/10803/10438/martinez2.pdf?...1

Martinez-Flor, A. (2005). A theoretical review of the speech act of suggesting: Towards a taxonomy for its use in FLT. Revista Alicantina de Estudios Ingleses, 18(1), 167-187.

Martinez-Flor, A., \& Uso-Juan, E. (2006). Pragmatic development in a second or foreign language: Some classroom technique. Greta, 14(1\&2), 50-56.

Matsumura, S. (2003). Modelling the relationships among interlanguage pragmatic development, L2 proficiency, and exposure to L2. Applied Linguistics, 24(4), 465-491.

Phisghadam, R \& Sharafadini, M. (2011). Delving into speech act of suggestion: A case of Iranian EFL learners. International Journal of Business and Social Science, 2(16), 152-160.

Rose, K. R. (2005). On the effects of instruction in second language pragmatics. System, 33(3), 385-399.

Safont-Jorda, M. (2003). Instructional effects on the use of request acts modification devices by EL learners. In A. Martinez lor, E. Uso Juan, \& A. Fernandez Guerra (Eds.), Pragmatic competence and foreign language teaching (pp. 211-232). Spain: Publicacions de la Universitat Jaume. 
. (2004). An analysis of EAP learners' pragmatic production: A focus on request forms. Iberica, 8, 23-39.

Schauer, G.A. (2006). Pragmatic awareness in ESL and EFL context: Contrast and development. Language Learning, 56(2), 269-318.

Schmidt, R. (1993). Awareness and second language acquisition. Annual Review of Applied Linguistics, 13, 206-226.

Suh, E. (2009). Metapragmatic requesting instruction in an adult basic educationESL classroom: Apilot study. Minnewitesol Journal, 26, 19-37.

Trosborg, A. (1995). Interlanguage pragmatics: request, complaints, and apologies. Berlin: Mouton de Gruyter.

Xiao-le, G. (2011). The effect of explicit and implicit instructions of request strategies. Intercultural Communication Studies, 20(1), 104-123. 


\section{Appendices}

Appendix 1. Taxonomy of Suggestion Linguistic Realization Strategies (Martinez-Flor, 2005: 175)

\begin{tabular}{|c|c|c|}
\hline Type & Strategy & Examples \\
\hline \multirow[t]{4}{*}{ Direct } & Performative Verb & $\begin{array}{l}\text { I suggest that you ... } \\
\text { I advise you to... } \\
\text { I recommend that you ... }\end{array}$ \\
\hline & Noun of Suggestions & My suggestion would be .... \\
\hline & Imperative & Try using .... \\
\hline & Negative Imperative & Dont try to .... \\
\hline \multirow[t]{5}{*}{ Conventionalized Forms } & $\begin{array}{l}\text { Specific Formulae } \\
\text { (Interrogative Form) }\end{array}$ & $\begin{array}{l}\text { Why dont you ....? } \\
\text { How about ....? } \\
\text { What about ....? } \\
\text { Have you thought about ....? }\end{array}$ \\
\hline & Possibility/Probability & $\begin{array}{l}\text { You can } \ldots . . \\
\text { You could } \ldots . . \\
\text { You may } \ldots . . \\
\text { You might } \ldots . .\end{array}$ \\
\hline & Should & You should .... \\
\hline & Need & You need to .... \\
\hline & Conditional & If I were you, I would .... \\
\hline \multirow[t]{2}{*}{ Indirect } & Impersonal & $\begin{array}{l}\text { One thing (that you can do) } \\
\text { would be .... } \\
\text { Heres one possibility.... } \\
\text { There are a number of options } \\
\text { that you .... } \\
\text { It would be helpful if you .... } \\
\text { It might be better to .... } \\
\text { A good idea would be .... } \\
\text { It would be nice if .... }\end{array}$ \\
\hline & Hints & I've heard that .... \\
\hline
\end{tabular}




\section{Appendix 2. External and Internal Modification Strategies}

(Trosborg, 1995)

External Modification Strategies

\begin{tabular}{|l|l|l|}
\hline \multicolumn{1}{|c|}{ Name } & \multicolumn{1}{|c|}{ Function } & \multicolumn{1}{c|}{ Examples } \\
\hline Grounder & $\begin{array}{l}\text { Provides reasons, explanations, and } \\
\text { justifications for the suggestions }\end{array}$ & $\begin{array}{l}\text { Erm, unfortunately, I really } \\
\text { dont understand this topic } \\
\text { here ..... }\end{array}$ \\
\hline Preparator & $\begin{array}{l}\text { Short utterance that intends to prepare the } \\
\text { hearer for the suggestions }\end{array}$ & May I give you a suggestion? \\
\hline $\begin{array}{l}\text { Imposition } \\
\text { Minimizer }\end{array}$ & $\begin{array}{l}\text { Reduces the imposition placed on the hearer } \\
\text { by the suggestion offered }\end{array}$ & $\begin{array}{l}\text { I will return them } \\
\text { immediately, the next day .... }\end{array}$ \\
\hline Disarmer & $\begin{array}{l}\text { Remove any potential objection the hearer } \\
\text { might raise }\end{array}$ & $\begin{array}{l}\text { I am not trying to be smart, } \\
\text { but I just need you to ...... }\end{array}$ \\
\hline
\end{tabular}

Internal Modification Strategies

\begin{tabular}{|l|l|l|l|}
\hline \multicolumn{1}{|c|}{ Type } & \multicolumn{1}{|c|}{ Name } & \multicolumn{1}{c|}{ Function } & \multicolumn{1}{c|}{ Examples } \\
\hline $\begin{array}{l}\text { Syntactic } \\
\text { Downgraders }\end{array}$ & Conditional Clause & $\begin{array}{l}\text { Employed by } \\
\text { speakers to distance } \\
\text { themselves from } \\
\text { the suggestion }\end{array}$ & $\begin{array}{l}\text { I would like to ask, if you } \\
\text { could maybe to do this } \\
\text { firsthand? }\end{array}$ \\
\cline { 2 - 4 } & Interrogative & $\begin{array}{l}\text { Used to downtone } \\
\text { the impact of the } \\
\text { suggestion by } \\
\text { appealing to the } \\
\text { hearers consent }\end{array}$ & $\begin{array}{l}\text { Could you p oint me the } \\
\text { clear solutions for this } \\
\text { problem? }\end{array}$ \\
\cline { 2 - 5 } & Negation & $\begin{array}{l}\text { Employed by } \\
\text { speakers to } \\
\text { downtone the force } \\
\text { of the suggestion by } \\
\text { indicating their } \\
\text { lowered } \\
\text { expectations of the } \\
\text { suggestion being } \\
\text { given }\end{array}$ & $\begin{array}{l}\text { You couldnt repeat what } \\
\text { you have explained please? }\end{array}$ \\
\hline Lexical/Phrasal \\
Downgraders & Appealer & $\begin{array}{l}\text { Used by the } \\
\text { speakers to appeal } \\
\text { the hearers } \\
\text { benevolent } \\
\text { understanding }\end{array}$ & $\begin{array}{l}\text { You know, you shouldnt } \\
\text { drink too much alcohol\& }\end{array}$ \\
& & & \\
\hline
\end{tabular}




\begin{tabular}{|l|l|l|l|}
\hline Type & \multicolumn{1}{|c|}{ Name } & \multicolumn{1}{c|}{ Function } & \multicolumn{1}{c|}{ Examples } \\
\hline & Hedge & $\begin{array}{l}\text { Used to indicate } \\
\text { tentativeness, } \\
\text { possibility and lack } \\
\text { of precision }\end{array}$ & $\begin{array}{l}\text { Is it possible if we can } \\
\text { arrange a meeting during } \\
\text { the holidays somehow? }\end{array}$ \\
\cline { 2 - 4 } & Politeness marker & $\begin{array}{l}\text { Employed by the } \\
\text { speakers to bid for } \\
\text { their hearers } \\
\text { cooperation }\end{array}$ & $\begin{array}{l}\text { Could you give more } \\
\text { explanation, please? }\end{array}$ \\
\cline { 2 - 5 } & Subjectivizer & $\begin{array}{l}\text { Explicitly } \\
\text { expressed by the } \\
\text { speaker to show his } \\
\text { or her subjective } \\
\text { opinion to the state } \\
\text { of affairs referred to } \\
\text { in the proposition }\end{array}$ & $\begin{array}{l}\text { Impelieve morality is } \\
\text { appearance... }\end{array}$ \\
\cline { 2 - 5 } & $\begin{array}{l}\text { Adverbial modifiers } \\
\text { used to } \\
\text { underrepresent the } \\
\text { state of affairs } \\
\text { referred to in the } \\
\text { proposition }\end{array}$ & $\begin{array}{l}\text { That might be a bit better } \\
\text { for us than the junk food\& }\end{array}$ \\
\hline
\end{tabular}




\section{Appendix 3. Discourse Completion Task (DCT)}

$\begin{array}{ll}\text { Year } & : \\ \text { Nationality } & : \\ \text { Sex } & \text { IELTS Score }\end{array}$

Direction: please respond these situations below and write down your response in a natural way as you talk to a real person.

Constellation 1: $[+\mathrm{P} /+\mathrm{D} /+\mathrm{R}]$

\section{Situation}

You meet a lecturer whom you are not very close with in a bookstore. He/she is going to buy an expensive book about Research Methods. Nevertheless, you have seen the cheap one in another bookstore. What suggestion would you make in this situation?

Your answer:

\section{Situation B}

A lecturer whom you are not very close with is a heavy smoker. You always think that he should stop smoking. While you are talking with him, he smokes again. What suggestion would you make in this situation?

Your answer:

Constellation 2: $[+\mathrm{P} /-\mathrm{D} /+\mathrm{R}]$

\section{Situation A}

You meet a lecturer whom you are very close with in a bookstore. He/she is going to buy an expensive book about Research Methods. Nevertheless, you have seen the cheap one in another bookstore. What suggestion would you make in this situation? 
Your answer:

\section{Situation B}

A lecturer whom you are very close with is a heavy smoker. You always think that he should stop smoking. While you are talking with him, he smokes again. What suggestion would you make in this situation?

Your answer:

Constellation 3: $[=\mathrm{P} /+\mathrm{D} /+\mathrm{R}]$

\section{Situation A}

You meet a friend whom you are not very close with in a parking lot. He/she likes to speed up his/her motorcycle in the street. You often think that he/she should stop doing it. What suggestion would you make in this situation?

Youranswer:

\section{Situation B}

You meet a friend whom you are not very close with in campus. He/she likes to go shopping and buy expensive things. You really know that he/she doesn't need them. What suggestion would you make in this situation?

Your answer:

Constellation 4: [=P/-D/+R]

\section{Situation A}

You meet a friend whom you are very close with in a parking lot. He/she likes to speed up his/her motorcycle in the street. You often think that he/she should stop doing it. What suggestion would you make in this situation?

Youranswer: 


\section{Situation B.}

You meet a friend whom you are very close with in campus. He/she likes to go shopping and buy expensive things. You really know that he/she doesn't need them. What suggestion would you make in this situation?

Your answer:

Constellation 5: $[=\mathrm{P} /+\mathrm{D} /-\mathrm{R}]$

\section{Situation A}

You are in a live class discussion with your classmates. Your friend who is not very close with you isn't really participating in the discussion. He/she is very smart but quite and a little shy, so he/she is probably worried of speaking out wrong opinions. You always felt that he/she should be more active and show his/her ability. What suggestion would you make in this situation?

Your answer:

\section{Situation B}

You go to a restaurant to have lunch there. You are very disappointed when you taste it because it tastes terrible. A friend who is not very close with you comes to have lunch as well. What suggestion would you make in this situation?

Your answer: 


\section{Appendix 4. DataAnalysis of RP1 and RP2}

Pre Role-play (RP1)

1. Constellation 1

Situation A: Why dont you buy the cheaper one in another bookstore? (Interrogative (CF))

Situation B: Smoking is not good (Grounder (Ex)), why do you still smoke? Interrogative $(\mathrm{CF})$

2. Constellation 2

Situation A: I think (Subjectivizer (In)) you should buy in another bookstore (Should (CF)).

Situation B: Smoking is not good for your health (Grounder (Ex)), I think (Subjectivizer (In)) you should stop smoking (Should (CF)).

3. Constellation 3

Situation A: What you did can harm youself and another one (Grounder (Ex)). Can you please be a bit (understater (In)) careful (Interrogative (CF)).

Situation B: Wow, you're rich, do you want to buy this clothes? (Hints (ID))

4. Constellation 4

Situation A: I think (Subjectivizer (In)) you should ride more carefully (Should $(\mathrm{CF})$ ). Afriend of mine got a fine yesterday (Grounder (Ex)).

Situation B: Do you need all things you bought? (Interrogative (In)) I don't think (Subjectivizer(In)) it's useful for you. How do you rekcon? (Hints (ID))

5. Constellation 5

Situation A: Hey, feel free to speak up (Imperative (D)). You have a great ideas to share, don't you? (Grounder (Ex))

Situation B: You'd better find another resto (Should (CF)), really disappointed with the maincourse (Grounder (Ex)). 
Total Suggestion : 10 Ô $40 \%$

Type: Direct : 1 Ô $10 \%$

CF $: 7 \hat{O} 70 \%$

Indirect : :20ิ $20 \%$

Modification: External :6(54,5\%)

Internal $: 5(45,4 \%)$

Post Role-play (RP2)

1. Constellation 1

Situation A: I think (Subjectivizer (In)) if u consider to buy it, you can get it in another book store which is cheaper. (Conditional (CF))

Situation B: Hi, Sorry, I have problem with smell the smoke from your cigarette (while holding his nose) (Hints (ID)). it is not good, this is the public place (Grounder (Ex)).

2. Constellation 2

Situation A: you want to buy that book right (Hedge (In))? I think (Subjectivizer (In)) I can accompany you to buy it in another bookstore which is cheaper (Grounder (Ex)). It's better for you to buy there (Impersonal (ID)).

Situation B: you still keep smoking, this is not good for you (Grounder (Ex)). I told you many..many times.. please (Politeness marker (In)) stop consider your own health (Imperative (D)). Please (Politeness marker (In)) consider it (Imperative (D)), you can die (Possibility (CF)). It's killed (Hints (ID)), you know (Appealer (In))

3. Constellation 3

Situation A: I always see you riding your motorbike very fast. I mean (Subjectivizer (In)), do you like to do like that? (Hints (ID)) I saw you this morning. You ride your motorbike very fast. (Grounder (Ex)) 
Situation B: Excuse me, mate! I think (Subjectivizer(In)) this is very expensive and you don't really need this one. (Hints (ID)) It's better for you to buy another thing (Should (CF)).

4. Constellation 4

Situation A: Hi mate, yesterday I saw you riding your motorbike so fast (Grounder (Ex)). Someday you will get a fine. (Hints (ID))

Situation B: I don't think (Subjectivizer (In)) it's very useful for you (Hints (ID)).

5. Constellation 5

Situation A: Hi mate, I reckon (Subjectivizer (In)) you have some good ideas to share (Hints (ID)). Don't be so hesitate and shy to express your idea (Neg. Imperative (D)).

Situation B: Hi mate, I was so disappointed with the dishes in this restaurant (Grounder(Ex)). Quite awful. (Hints (ID))

Total : $15 \hat{O} \quad 60 \%$

Type : Direct:3 Ô 20\%

$\mathrm{CF}: 3 \mathrm{O} \quad 20 \%$

Indirect: 9 Ô 60\%

Modification : Internal: 9 Ô $60 \%$

External: 6 Ô $40 \%$ 